\title{
The impact of antihypertensives on kidney disease [version 1;
}

\section{peer review: 2 approved]}

\author{
Diego F Marquez¹, Gema Ruiz-Hurtado², Luis Ruilope ${ }^{2-4}$
}

${ }^{1}$ Unidad de Hipertensión Arterial, Servicio de Medicina Clínica, Hospital San Bernardo, Salta, Argentina

2Instituto de Investigación Imas12 and Unidad de Hipertensión, Hospital 12 de Octubre, Madrid, Spain

${ }^{3}$ Departamento de Medicina Preventiva y Salud Pública, Universidad Autónoma, Madrid, Spain

${ }^{4}$ Escuela de Estudios Postdoctorales and Investigación, Universidad de Europa de Madrid, Madrid, Spain

V1 First published: 02 May 2017, 6(F1000 Faculty Rev):611

https://doi.org/10.12688/f1000research.9916.1

Latest published: 02 May 2017, 6(F1000 Faculty Rev):611

https://doi.org/10.12688/f1000research.9916.1

\section{Abstract}

Arterial hypertension and chronic kidney disease (CKD) are intimately related. The control of blood pressure (BP) levels is strongly recommended in patients with CKD in order to protect the kidney against the accompanying elevation in global cardiovascular (CV) risk. Actually, the goal BP in patients with CKD involves attaining values $<140 / 90 \mathrm{mmHg}$ except if albuminuria is present. In this case, it is often recommended to attain values $<130 / 80 \mathrm{mmHg}$, although some guidelines still recommend $<140 / 90 \mathrm{mmHg}$. Strict BP control to values of systolic BP around $120 \mathrm{mmHg}$ was recently shown to be safe in CKD according to data from the SPRINT trial, albeit more data confirming this benefit are required. Usually, combination therapy initiated with an angiotensin receptor blocker (ARB) or angiotensin-converting enzyme inhibitor (ACEi) and commonly followed by the addition of a calcium channel blocker and a diuretic is needed. Further studies are required as well as new drugs in particular after the positive data obtained from new oral anti-diabetic drugs.

\section{Keywords}

arterial hypertension, chronic kidney disease, CKD, antihypertensives, kidney disease

\section{Open Peer Review}

Approval Status

1

2

version 1

02 May 2017

Faculty Reviews are review articles written by the prestigious Members of Faculty Opinions. The articles are commissioned and peer reviewed before publication to ensure that the final, published version is comprehensive and accessible. The reviewers who approved the final version are listed with their names and affiliations.

1. Paul Cockwell, Department of Nephrology, University Hospitals Birmingham NHS Foundation Trust, Birmingham, UK

2. Keith C. Norris ID, David Geffen School of Medicine at University of California, Los

Angeles, Los Angeles, USA

Any comments on the article can be found at the end of the article. 
Corresponding author: Luis Ruilope (ruilope@ad-hocbox.com)

Competing interests: The authors declare that they have no competing interests.

Grant information: This article was written with the help of Instituto de Salud Carlos III, projects PI14/01841 and CP15/0129, Fundación Senefro, and Fondos FEDER.

The funders had no role in study design, data collection and analysis, decision to publish, or preparation of the manuscript.

Copyright: @ 2017 Marquez DF et al. This is an open access article distributed under the terms of the Creative Commons Attribution License, which permits unrestricted use, distribution, and reproduction in any medium, provided the original work is properly cited.

How to cite this article: Marquez DF, Ruiz-Hurtado G and Ruilope L. The impact of antihypertensives on kidney disease [version 1; peer review: 2 approved] F1000Research 2017, 6(F1000 Faculty Rev):611 https://doi.org/10.12688/f1000research.9916.1

First published: 02 May 2017, 6(F1000 Faculty Rev):611 https://doi.org/10.12688/f1000research.9916.1 


\section{Introduction}

Clinical and epidemiological evidence has demonstrated the importance of blood pressure (BP) control in order to prevent the development and to reduce the progression of chronic kidney disease $(\mathrm{CKD})^{1}$. On the other hand, CKD is accompanied by a very significant increase in cardiovascular (CV) risk ${ }^{2}$. As a consequence, the treatment of arterial hypertension is simultaneously directed to promote renal and $\mathrm{CV}$ protection. It is widely accepted that suppression of the renin-angiotensin-aldosterone system (RAAS) through the use of an angiotensin-converting enzyme inhibitor (ACEi) or an angiotensin receptor blocker (ARB) constitutes the first step of therapy in patients with $\mathrm{CKD}^{1}$.

Studies examining the effect that antihypertensives have on kidney function have typically involved early or pre-existing primary renal disease and/or diabetic nephropathy patients. These trials were devoted primarily to investigating the evolution of renal function during a short period of time and in relatively small samples that impeded our knowledge of the simultaneous effects on CV outcome ${ }^{3}$. Initially, the capacity of ACEi and ARB for the diminution and primary prevention of albuminuria in CKD, and particularly in type 2 diabetics, was investigated ${ }^{3-5}$. The changes in albuminuria together with the control of arterial hypertension were determinants for the improvement in renal outcomes ${ }^{3}$. However, recent data have also shown that in hypertensive CKD patients with low levels of albuminuria, the exclusive attainment of low BP goals is associated with an improvement in eGFR $^{6}$. Thus, in CKD patients, the presence of albuminuria is considered in KDIGO and several other guidelines as the key point to recommend a stricter BP goal $(\leq 130 \mathrm{mmHg}$ systolic and $\leq 80 \mathrm{mmHg}$ diastolic if albumin excretion rate is $\geq 30 \mathrm{mg} / 24$ hours $)^{7,8}$. A similar BP goal may be considered in patients with low or no level of albuminuria. In fact, the renal data of the SPRINT trial indicate that a SBP goal lower than $120 \mathrm{mmHg}$ was safe and effective in a subgroup of patients with CKD? .

\section{Hypertension as a mediator of the correlation between chronic kidney disease and cardiovascular disease}

Albuminuria, increased serum creatinine values, and a lower eGFR are considered by current arterial hypertension guidelines as significant $\mathrm{CV}$ risk factors that add to the already-high risk of pre-existing $\mathrm{CV}$ risk factors such as diabetes, cholesterol, and smoking $^{10,11}$. In fact, patients developing end-stage renal disease (ESRD) and entering dialysis are a minority among the CKD population; one could also consider them to be survivors, as a large number of patients with CKD die from CV disease before ESRD develops. As can be seen in the article published by Levey et $a{ }^{12}{ }^{12}$ with data from the USA, $4.9 \%$ of the total CKD population has an eGFR below $60 \mathrm{~mL} /$ minute $/ 1.73 \mathrm{~m}^{2}$. This represents a very relevant number of patients with CKD in stages $3 a, 3 b, 4$, and 5 , but only $0.2 \%$ attain the stage ${ }^{12}$. These data are obtained from different surveys (NHANES) performed in the US, and since these are cross-sectional data it does not capture the fact that many patients die before reaching the terminal stages of CKD. Recently, we published a review ${ }^{13}$ showing that data from some clinical trials in the field of arterial hypertension have demonstrated that $\mathrm{CV}$ and renal protection can be attained simultaneously using the same therapy, mainly consisting of a renin-angiotensin-aldosterone system (RAAS) blocker, a calcium antagonist, and a diuretic, to which a statin is frequently added. These data indicate that early and aggressive control of hypertension and albuminuria is very important to simultaneously protect the $\mathrm{CV}$ and renal systems.

Unfortunately, many patients attain the advanced stages of CKD, where RAAS blockade is often incomplete in a relevant percentage of patients, particularly in stages $3 \mathrm{~b}$ and 4 of CKD, not tolerating high doses owing to the frequent development of hyperkalemia. The recent development of new potassium binders will contribute to facilitating the long-term maintenance of RAAS blockers, in particular mineralocorticoid receptor antagonists, while maintaining adequate serum potassium levels ${ }^{14,15}$.

\section{Antihypertensive therapy, blood pressure goals, and renal function}

Different mechanisms play a key role in the development and maintenance of hypertension in CKD. The most important of them are volume overload, due to the difficulty in sodium and water handling, and activation of the RAAS and of the sympathetic nervous system ${ }^{2}$. These effects influence intraglomerular pressure negatively through the facilitation of the pulsatile transmission of uncontrolled systemic $\mathrm{BP}^{16}$. The renoprotection provided by antihypertensive agents depends on their capacity to lower systemic BP, impeding the damage in the renal vasculature from the arteries to the renal microcirculation and to the glomeruli through their specific effects on renal hemodynamics ${ }^{16}$. Usually, the combination of more than two drugs is needed to attain an adequate control that depends on counteracting the three main factors intervening in the development and progression of hypertension.

The goal BP for CKD is commonly recommended to be below $140 / 90 \mathrm{mmHg}$, except when albuminuria is presented. The abandoning of the prior commonly recommended BP goal of $<130 / 80 \mathrm{mmHg}$ in patients with CKD was due to the failure of randomized controlled trials (RCTs) devoted to investigating strict BP control in CKD to show benefit, particularly the Modification of Diet in Renal Disease (MDRD) study ${ }^{17}$, the BP Control for Renoprotection in Patients with Nondiabetic Chronic Renal Disease (REIN-2) trial ${ }^{18}$, and the African American Study of Kidney Disease (AASK) ${ }^{19}$. A secondary analysis of the AASK trial reported that strict BP control in patients with albuminuria $>0.22 \mathrm{~g} / \mathrm{g}$ creatinine had fewer composite endpoints (HR $0.73, \mathrm{p}=0.01)^{20}$, confirming the adequacy of lower goal BP with albuminuria. Interestingly, a long-term combined analysis of the MDRD and AASK studies showed that strict BP control did not delay the onset of ESRD but did reduce the relative risk of death in patients with $\mathrm{CKD}(0.87,95 \%$ confidence interval [CI] 0.76-0.99) during long-term follow up ${ }^{21}$.

On the other hand, data published as a meta-analysis of 11 randomized controlled trials in non-diabetic renal disease patients demonstrated that an SBP of 110-129 $\mathrm{mmHg}$ was associated with a lower risk for progressive renal disease ${ }^{22}$. Interestingly, increased renal risk was observed with $\mathrm{SBP}$ values of $<110 \mathrm{mmHg}$; this is in line with the potential negative effects on the kidney caused by a significant drop in renal perfusion pressure after the consequences of a maintained elevation of BP and the development of nephrosclerosis have taken their toll on the renal vasculature ${ }^{23}$. 
Other data related to mortality in patients with CKD indicate that the optimal BP differs and oscillates between 130 and 159/70 and $89 \mathrm{mmHg}^{24}$. The progression of diabetic and non-diabetic renal disease was more effectively slowed down, and survival was also improved, when patients were administered an antihypertensive regime that included an $\mathrm{ACEi}$ or an $\mathrm{ARB}$ compared to a regime without; this observation was independent of attained $\mathrm{BP}^{25}$. On the other hand, dual blockade of the RAAS using ACEi plus ARB simultaneously did not show benefits in large-scale trials $^{26-28}$. In the same way, the addition of the direct renin inhibitor aliskiren to standard therapy with a RAAS blocker in high CV risk patients with diabetes is not supported and may even be harmful ${ }^{28}$. As a consequence, combined use of the two RAAS blockers in patients with CKD has been discarded by guidelines $^{8,29}$.

Data from the Action to Control Cardiovascular Risk in Diabetes (ACCORD) study ${ }^{30}$ indicate that strict BP control (SBP $<120 \mathrm{mmHg}$ ) did not improve renal outcomes of type 2 diabetic patients, and according to several reports the SBP goal of $<130 \mathrm{mmHg}$ remains adequate in this condition for renal and CV protection ${ }^{13,31}$.

\section{Blockade of aldosterone: an unfulfilled promise?}

Aldosterone is a relevant mediator of progressive renal and CV damage $^{32}$. It is well known that aldosterone antagonists reduce albuminuria in patients with CKD, on top of a RAAS blocker, by an amount of $30-40 \% \%^{33-35}$. As previously mentioned, a limiting factor for the wide use of aldosterone antagonists is linked with the risk of inducing hyperkalemia, which becomes a prominent concern as renal function deteriorates. Finerenone is a novel nonsteroidal mineralocorticoid receptor antagonist (MRA) that has greater receptor selectivity than spironolactone and eplerenone, can significantly decrease albuminuria in diabetic nephropathy, and has a much lower prevalence of hyperkalemia ${ }^{36}$. Actually, two seminal studies are ongoing to test the capacity of the new MRA finerenone to slow down the progression of diabetic nephropathy (NCT02540993) $^{37}$ and to protect the CV system in type 2 diabetic patients (NCT02545049) ${ }^{38}$. The use of the new potassium binder patiromer and the selective cation exchanger sodium zirconium cyclosilicate ${ }^{15}$ will contribute to the facilitation of MRA use in patients with CKD.

\section{Evidence with other therapies and renal outcomes}

Recently, new data on the role of sodium intake in the progression of $\mathrm{CV}$ disease ${ }^{39}$ and renal disease $\mathrm{e}^{40-42}$ have been published, enhancing the need for an adequate intake of sodium in patients with CKD. A low-sodium diet contributes to the reduction of albuminuria by itself and through the enhancement of RAAS blockade ${ }^{40,41}$. On the other hand, there are drugs other than hypertensives that can positively influence renal function together with BP control, such as statins ${ }^{43}$, fibrates ${ }^{44}$, thiazolidinediones ${ }^{45}$, and antiplatelet therapy ${ }^{46}$. Treatments such as allopurinol ${ }^{47}$ and vitamin D supplementation ${ }^{48}$ require further investigation.

Recently, the results of the EMPA-REG trial showed a lower rate of $\mathrm{CV}$ death, total death, and heart failure in type 2 diabetic patients with the addition of empagliflozin to standard care ${ }^{49}$. Moreover, the analysis of secondary end points of the EMPAREG trial showed that empagliflozin was associated with a slower progression of $\mathrm{CKD}^{50}$. These good results were partially due to the antihypertensive and natriuretic capacities of the drugs ${ }^{51}$.

Results obtained with GLP-1 agonists liraglutide ${ }^{52}$ and semaglutide $^{53}$ have also shown a significant improvement in $\mathrm{CV}$ outcomes of type 2 diabetics that was accompanied by a more significant decrease in body weight and a less important drop in BP in the absence of natriuretic effects. This last point could explain the absence of effects on heart failure. Liraglutide also exhibited a renal protective capacity through a significant decrease in albuminuria $^{52}$. Further studies will be presented in the near future with these two classes of drugs and will contribute to the reconsideration of type 2 diabetes treatment with regard to $\mathrm{CV}$ and renal protection.

In summary, strict BP control, adequate suppression of the RAAS, and an integrated approach to protection of the increased global $\mathrm{CV}$ risk are required to prevent the appearance and progression of $\mathrm{CKD}$ and simultaneously of CV disease. New drugs are coming that could facilitate the control of BP and improve both renal and CV outcomes.

\section{Competing interests}

The authors declare that they have no competing interests.

\section{Grant information}

This article was written with the help of Instituto de Salud Carlos III, projects PI14/01841 and CP15/0129, Fundación Senefro, and Fondos FEDER.

The funders had no role in study design, data collection and analysis, decision to publish, or preparation of the manuscript.
1. Qaseem A, Hopkins RH Jr, Sweet DE, et al.: Screening, monitoring, and treatment of stage 1 to 3 chronic kidney disease: A clinical practice guideline from the American College of Physicians. Ann Intern Med. 2013; 159(12): 835-47. PubMed Abstract | Publisher Full Text
2.

Gansevoort RT, Correa-Rotter R, Hemmelgarn BR, et al:: Chronic kidney disease and cardiovascular risk: epidemiology, mechanisms, and prevention. Lancet. 2013; 382(9889): 339-52.

PubMed Abstract | Publisher Full Text 
3. Ruilope LM, Segura J, Fujita T, et al.: Renal and cardiovascular events: do they deserve the same consideration in clinical trials? J Hypertens. 2009; 27(9): 1743-5.

PubMed Abstract | Publisher Full Text

4. Ruggenenti P, Fassi A, llieva AP, et al.: Preventing microalbuminuria in type 2 diabetes. N Engl J Med. 2004; 351(19): 1941-51.

PubMed Abstract | Publisher Full Text

5. $\quad \mathrm{F}$ Haller $\mathrm{H}$, Ito $\mathrm{S}$, Izzo JL Jr, et al:: Olmesartan for the delay or prevention of microalbuminuria in type 2 diabetes. N Engl J Med. 2011; 364(10): 907-17. PubMed Abstract | Publisher Full Text | F1000 Recommendation

6. Hu B, Gadegbeku C, Lipkowitz MS, et al.: Kidney function can improve in patients with hypertensive CKD. J Am Soc Nephrol. 2012; 23(4): 706-13. PubMed Abstract | Publisher Full Text | Free Full Text

7. Wheeler DC, Becker GJ: Summary of KDIGO guideline. What do we really know about management of blood pressure in patients with chronic kidney disease? Kidney Int. 2013; 83(3): 377-83.

PubMed Abstract | Publisher Full Text

8. Mancia G, Fagard R, Narkiewicz K, et al: 2013 ESH/ESC guidelines for the management of arterial hypertension: the Task Force for the Management of Arterial Hypertension of the European Society of Hypertension (ESH) and of the European Society of Cardiology (ESC). Eur Heart J. 2013; 34(28): 2159-219. PubMed Abstract | Publisher Full Text

9. $\quad F$ SPRINT Research Group, Wright JT Jr, Williamson JD, et al:: A Randomized Trial of Intensive versus Standard Blood-Pressure Control. N Engl J Med. 2015; 373(22): 2103-16.

PubMed Abstract | Publisher Full Text | Free Full Text | F1000 Recommendation

10. van der Velde M, Matsushita K, Coresh J, et al.: Lower estimated glomerula filtration rate and higher albuminuria are associated with all-cause and cardiovascular mortality. A collaborative meta-analysis of high-risk population cohorts. Kidney Int. 2011; 79(12): 1341-52.

PubMed Abstract | Publisher Full Tex

11. Gansevoort RT, Matsushita K, van der Velde M, et al.: Lower estimated GFR and higher albuminuria are associated with adverse kidney outcomes. A collaborative meta-analysis of general and high-risk population cohorts. Kidney Int. 2011; 80(1): 93-104.

PubMed Abstract | Publisher Full Text | Free Full Text

12. Levey AS, de Jong PE, Coresh J, et al.: The definition, classification, and prognosis of chronic kidney disease: a KDIGO Controversies Conference report. Kidney Int. 2011; 80(1): 17-28.

PubMed Abstract | Publisher Full Tex

13. Ruiz-Hurtado G, Sarafidis P, Fernández-Alfonso MS, et al.: Global cardiovascula protection in chronic kidney disease. Nat Rev Cardiol. 2016; 13(10): 603-8. PubMed Abstract | Publisher Full Text

14. F Rossignol P, Massy ZA, Azizi M, et al:: The double challenge of resistant hypertension and chronic kidney disease. Lancet. 2015; 386(10003): 1588-98. PubMed Abstract | Publisher Full Text | F1000 Recommendation

15. Zannad F, Rossignol P, Stough WG, et al.: New approaches to hyperkalemia in patients with indications for renin angiotensin aldosterone inhibitors: Considerations for trial design and regulatory approval. Int J Cardiol. 2016; 216: $46-51$.

PubMed Abstract | Publisher Full Text

16. Levey AS, Coresh J: Chronic kidney disease. Lancet. 2012; 379(9811): 165-180 PubMed Abstract | Publisher Full Text

17. Klahr S, Levey AS, Beck GJ, et al:: The effects of dietary protein restriction and blood-pressure control on the progression of chronic renal disease. Modification of Diet in Renal Disease Study Group. N Engl J Med. 1994; 330(13): 877-84.

PubMed Abstract | Publisher Full Text

18. Ruggenenti P, Perna A, Loriga G, et al:: Blood-pressure control for renoprotection in patients with non-diabetic chronic renal disease (REIN-2): multicentre, randomised controlled trial. Lancet. 2005; 365(9463): 939-46. PubMed Abstract | Publisher Full Text

19. Wright JT Jr, Bakris G, Greene T, et al.: Effect of blood pressure lowering and antihypertensive drug class on progression of hypertensive kidney disease: results from the AASK trial. JAMA. 2002; 288(19): 2421-31.

PubMed Abstract | Publisher Full Text

20. F Appel LJ, Wright JT Jr, Greene T, et al:: Intensive blood-pressure control in hypertensive chronic kidney disease. N Engl J Med. 2010; 363(10): 918-29. PubMed Abstract | Publisher Full Text | Free Full Text | F1000 Recommendation

21. F Ku E, Gassman J, Appel LJ, et al.: BP Control and Long-Term Risk of ESRD and Mortality. J Am Soc Nephrol. 2017; 28(2): 671-7. PubMed Abstract | Publisher Full Text | Free Full Text | F1000 Recommendation

22. Jafar TH, Stark PC, Schmid CH, et al.: Progression of chronic kidney disease: the role of blood pressure control, proteinuria, and angiotensin-converting enzyme inhibition: a patient-level meta-analysis. Ann Intern Med. 2003; 139(4): 244-52

PubMed Abstract | Publisher Full Text

23. Toto RD: Renal insufficiency due to angiotensin-converting enzyme inhibitors Miner Electrolyte Metab. 1994; 20(4): 193-200. PubMed Abstract

24. $\mathrm{F}$ Kovesdy $\mathrm{CP}$, Bleyer AJ, Molnar MZ, et al.: Blood pressure and mortality in
U.S. veterans with chronic kidney disease: a cohort study. Ann Intern Med. 2013; 159(4): 233-42.

PubMed Abstract | Publisher Full Text | Free Full Text | F1000 Recommendation

25. Damman K, Lambers-Heerspink $\mathrm{HJ}$ : Are renin-angiotensin-aldosterone system inhibitors lifesaving in chronic kidney disease? J Am Coll Cardiol. 2014; 63(7): 659-60.

PubMed Abstract | Publisher Full Tex

26. F ONTARGET Investigators, Yusuf S, Teo KK, et al.: Telmisartan, ramipril, or both in patients at high risk for vascular events. N Engl J Med. 2008; 358(15) $1547-59$

PubMed Abstract | Publisher Full Text | F1000 Recommendation

27. F Fried LF, Emanuele N, Zhang JH, et al:: Combined angiotensin inhibition for the treatment of diabetic nephropathy. N Engl J Med. 2013; 369(20): 1892-903. PubMed Abstract | Publisher Full Text | F1000 Recommendation

28. F Parving HH, Brenner BM, McMurray JJ, et al:: Cardiorenal end points in a trial of aliskiren for type 2 diabetes. N Engl J Med. 2012; 367(23): 2204-13. PubMed Abstract | Publisher Full Text | F1000 Recommendation

29. James PA, Oparil S, Carter BL, et al:: $\mathbf{2 0 1 4}$ evidence-based guideline for the management of high blood pressure in adults: report from the panel members appointed to the Eighth Joint National Committee (JNC 8). JAMA. 2014; 311(5): 507-20.

PubMed Abstract | Publisher Full Text

30. F ACCORD Study Group, Cushman WC, Evans GW, et al:: Effects of intensive blood-pressure control in type 2 diabetes mellitus. N Engl J Med. 2010; 362(17) 1575-85.

PubMed Abstract | Publisher Full Text | Free Full Text | F1000 Recommendation

31. F Ettehad D, Emdin CA, Kiran A, et al:: Blood pressure lowering for prevention of cardiovascular disease and death: a systematic review and meta-analysis. Lancet. 2016; 387(10022): 957-67.

PubMed Abstract | Publisher Full Text | F1000 Recommendation

32. Hostetter TH, Ibrahim HN: Aldosterone in chronic kidney and cardiac disease. J Am Soc Nephrol. 2003; 14(9): 2395-401.

PubMed Abstract | Publisher Full Text

33. Márquez DF, Ruiz-Hurtado G, Ruilope LM, et al.: An update of the blockade of the renin angiotensin aldosterone system in clinical practice. Expert Opin Pharmacother. 2015; 16(15): 2283-92.

PubMed Abstract | Publisher Full Text

34. Mehdi UF, Adams-Huet B, Raskin P, et al:: Addition of angiotensin receptor blockade or mineralocorticoid antagonism to maximal angiotensin-converting enzyme inhibition in diabetic nephropathy. J Am Soc Nephrol. 2009; 20(12): 2641-50. PubMed Abstract | Publisher Full Text | Free Full Text

35. Bomback AS, Kshirsagar AV, Amamoo MA, et al:: Change in proteinuria after adding aldosterone blockers to ACE inhibitors or angiotensin receptor blockers in CKD: a systematic review. Am J Kidney Dis. 2008; 51(2): 199-211. PubMed Abstract | Publisher Full Text

36. Bakris GL, Agarwal R, Chan JC, et al:: Effect of Finerenone on Albuminuria in Patients With Diabetic Nephropathy: A Randomized Clinical Trial. JAMA. 2015; 314(9): 884-94

PubMed Abstract | Publisher Full Text

37. Bayer: Efficacy and Safety of Finerenone in Subjects With Type 2 Diabetes Mellitus and Diabetic Kidney Disease (FIDELIO-DKD). NCT02540993. Reference Source

38. Bayer: Efficacy and Safety of Finerenone in Subjects With Type 2 Diabetes Mellitus and the Clinical Diagnosis of Diabetic Kidney Disease (FIGARO-DKD). NCT02545049. Reference Source

39. F Cook NR, Appel LJ, Whelton PK: Sodium Intake and All-Cause Mortality Over 20 Years in the Trials of Hypertension Prevention. J Am Coll Cardiol. 2016; 68(15): 1609-17.

PubMed Abstract | Publisher Full Text | Free Full Text | F1000 Recommendation

40. F Sanghavi S, Vassalotti JA: Dietary sodium: a therapeutic target in the treatment of hypertension and CKD. J Ren Nutr. 2013; 23(3): 223-7. PubMed Abstract| Publisher Full Text |F1000 Recommendation

41. Powe NR, Bibbins-Domingo K: Dietary Salt, Kidney Disease, and Cardiovascular Health. JAMA. 2016; 315(20): 2173-4. PubMed Abstract | Publisher Full Tex

42. F Mills KT, Chen J, Yang W, et al:: Sodium Excretion and the Risk of Cardiovascular Disease in Patients With Chronic Kidney Disease. JAMA. 2016; 315(20): 2200-10

PubMed Abstract | Publisher Full Text | Free Full Text | F1000 Recommendation

43. Douglas K, O'Malley PG, Jackson JL: Meta-analysis: the effect of statins on albuminuria. Ann Intern Med. 2006; 145(2): 117-24.

PubMed Abstract | Publisher Full Tex

44. Jun $\mathrm{M}$, Zhu $\mathrm{B}$, Tonelli $\mathrm{M}$, et al: Effects of fibrates in kidney disease: a systematic review and meta-analysis. J Am Coll Cardiol. 2012; 60(20): 2061-71. PubMed Abstract | Publisher Full Text

45. Sarafidis PA, Bakris GL: Protection of the kidney by thiazolidinediones: an assessment from bench to bedside. Kidney Int. 2006; 70(7): 1223-33. PubMed Abstract | Publisher Full Text

46. Jardine MJ, Ninomiya T, Perkovic V, et al:: Aspirin is beneficial in hypertensive 
patients with chronic kidney disease: a post-hoc subgroup analysis of a randomized controlled trial. J Am Coll Cardiol. 2010; 56(12): 956-65. PubMed Abstract | Publisher Full Text

47. Kabul S, Shepler B: A review investigating the effect of allopurinol on the progression of kidney disease in hyperuricemic patients with chronic kidney disease. Clin Ther. 2012; 34(12): 2293-6. PubMed Abstract | Publisher Full Text

48. Anker SD, von Haehling S: Vitamin D in chronic kidney disease: more questions than answers. JAMA. 2012; 307(7): 722-3. PubMed Abstract | Publisher Full Text

49. F Zinman B, Wanner C, Lachin JM, et al:: Empagliflozin, Cardiovascula Outcomes, and Mortality in Type 2 Diabetes. N Engl J Med. 2015; 373(22): 2117-28. PubMed Abstract | Publisher Full Text | F1000 Recommendation

50. Wanner C, Inzucchi SE, Lachin JM, et al.: Empagliflozin and Progression of Kidney Disease in Type 2 Diabetes. N Engl J Med. 2016; 375(4): 323-34. PubMed Abstract | Publisher Full Text

51. Heise T, Seewaldt-Becker E, Macha S, et al:: Safety, tolerability, pharmacokinetics and pharmacodynamics following 4 weeks' treatment with empagliflozin once daily in patients with type 2 diabetes. Diabetes Obes Metab. 2013; 15(7): 613-21.

PubMed Abstract | Publisher Full Text

52. $\mathrm{F}$ Marso SP, Daniels GH, Brown-Frandsen $\mathrm{K}$, et al.: Liraglutide and Cardiovascular Outcomes in Type 2 Diabetes. N Engl J Med. 2016; 375(4): 311-22.

PubMed Abstract | Publisher Full Text | Free Full Text | F1000 Recommendation

53. Marso SP, Bain SC, Consoli A, et al:: Semaglutide and Cardiovascular Outcomes in Patients with Type 2 Diabetes. N Engl J Med. 2016; 375(19): 1834-44. PubMed Abstract | Publisher Full Text 


\section{Open Peer Review}

\section{Current Peer Review Status:}

\section{Editorial Note on the Review Process}

Faculty Reviews are review articles written by the prestigious Members of Faculty Opinions. The articles are commissioned and peer reviewed before publication to ensure that the final, published version is comprehensive and accessible. The reviewers who approved the final version are listed with their names and affiliations.

\section{The reviewers who approved this article are:}

\section{Version 1}

\section{Keith C. Norris}

David Geffen School of Medicine at University of California, Los Angeles, Los Angeles, CA, USA

Competing Interests: No competing interests were disclosed.

\section{Paul Cockwell}

Department of Nephrology, University Hospitals Birmingham NHS Foundation Trust, Birmingham, UK Competing Interests: No competing interests were disclosed.

The benefits of publishing with F1000Research:

- Your article is published within days, with no editorial bias

- You can publish traditional articles, null/negative results, case reports, data notes and more

- The peer review process is transparent and collaborative

- Your article is indexed in PubMed after passing peer review

- Dedicated customer support at every stage

For pre-submission enquiries, contact research@f1000.com 